\title{
Retraction Note to: Familial Aplasia of the Olfactory Bulb
}

\author{
A Report of Two Cases
}

\section{Solymosi}

Published online: 14 April 2012

(C) Springer-Verlag Berlin Heidelberg 2012

\section{Retraction to: Clin Neuroradiol (2012) \\ DOI 10.1007/s00062-012-0148-z \\ Familial Aplasia of the Olfactory Bulb. A Report of Two Cases \\ R. E. Bolt, L. Zipp, S. Partovi, S. Karimi, J. K. Lyo, C. Stippich}

Clinical Neuroradiology and its editorial staff are deeply committed to publishing integrity and follow the guidelines of the Committee on Publication Ethics (COPE) and therefore are obliged to inform the readership about the retraction of the article mentioned above.

Revision of the above-mentioned article, as carried out by Prof. Stippich in collaboration with a faculty representative for scientific integrity, has brought aspects to light which make it necessary to retract the publication for reasons of form, content and ethico-legal considerations. Clinical data were used for the publication without the knowledge and approval of the clinical partner discipline. The appropriate colleague was not informed about the preparation of the manuscript, involved in its composition, or mentioned as an author in the acknowledgements. Some passages of the text referring to endocrinological and genetic tests were not based on own data. R. E. Bolt would hereby like to formally apologise for his scientific misconduct and for any inconvenience it may have caused.
C. Stippich would hereby like to inform that he was not involved in the preparation of the above-mentioned article and that he did not give his approval for the article to be published in association with his name. The article was submitted to Clinical Neuroradiology for publication without his knowledge and approval. Thus, the publication was not appropriately reviewed, revised or approved for publication. C. Stippich has not submitted any works of his own for this publication and formally distances himself from the publication in question.

L. Zipp, S. Partovi and J. K. Lyo received an inquiry to revise the manuscript which the corresponding author had written and to make corrections in the draft provided by the corresponding author. The authors named were not aware of any scientific misconduct and distance themselves from the publication in question.

S. Karimi could not be reached for comment.

The authors and editorial staff of Clinical Neuroradiology apologise for any inconvenience.

László Solymosi

(Editor-in-Chief)

L. Solymosi ( $ه)$

Würzburg, Germany

e-mail: solymosi@neuroradiologie.uni-wuerzburg.de 